\title{
Chapter 3 \\ Shifting Imageries: Gentrification \\ and the New Touristic Images \\ of the Inner City of Palermo
}

\author{
Marco Picone
}

\subsection{Theoretical Framework: Place Identities, Urban Imageries and Gentrification}

This chapter draws upon the theory of local-scale territorial identity to analyse how the urban imagery of the inner city of Palermo (Italy) has been shaped by the latest urban policies concerning gentrification and touristification. Therefore, the whole chapter revolves around three theoretical concepts that will be discussed in the following lines.

\subsubsection{Place Identities}

The notion of place identity, or territorial identity, according to French and Italian geographic literature, has been thoroughly discussed over the last few decades. While Anglo-American scholars preferably focus on the idea of regional identity (Paasi 2003, 2010), others proposed the notion of local-scale identity "for two main reasons: first, because local is the scale where international political priorities (sustainability, production of cultural specificity, participation in decision-making processes, etc.) can be socially implemented; second, because local is also the scale where people's knowledge, memories, values, experiences, practices make territory a space of both collective significance and possible shared social action" (Banini 2017, p. 17).

However, using the word 'territory' calls for some caution. I agree with Stuart Elden's claim that "territory is often assumed to be self-evident in meaning, allowing the study of its particular manifestations - territorial disputes, the territory of specific countries, etc. - without theoretical reflection on 'territory' itself' (Elden 2010,

\footnotetext{
M. Picone $(\varangle)$

Department of Architecture, University of Palermo, Palermo, Italy

e-mail: marco.picone@unipa.it
} 
p. 800). In this chapter, I will use 'territory' as Swiss geographer Claude Raffestin suggests in his seminal book Pour une géographie du pouvoir (1980): territory and space are not equivalent terms; on the contrary, territory is generated from space through the actions of social actors who 'territorialise' space.

Other scholars prefer the word 'place' rather than 'territory', by distinguishing 'space' from 'place' and considering the former to be any simple location with no socially perceived relevance for human beings, and the latter as the result of the social constructions of meaning performed by those who live there (Tuan 1977). However, it is also "difficult to take a word such as place, which is in everyday use and applied in all sorts of ways, and turn it into a concept that has a precise and operational meaning" (Friedmann 2010, p. 152; see also Cresswell 2004).

Regardless of the personal preferences for place, territory or other terms, most scholars concur that the "identity of the place" (Banini 2017, p. 19) is the result of long and complex performative processes, involving multiple actors for a relatively long span of time. This proves to be true both at the global and at the local scale. As Doreen Massey states, space (though in this case we could probably use the word 'place' instead) is the product of interrelations and must thus be recognised as "constituted through interactions, from the immensity of the global to the intimately tiny" (Massey 2005, p. 9).

What matters for this chapter, essentially, is that in the case of cities one might say that place identity is the product of social, political and economic interrelations of social actors. The identity of a neighbourhood can change according to the social processes its citizens enact. This notion, which most social scientists have agreed upon over the last few decades, will prove vital for the analysis of what happened in the inner city of Palermo.

\subsubsection{Urban Imageries}

The social construction of places is tightly connected to the way those same places are represented. "Representational strategies stem from a highly selective and politicized process. In order to build consensus among its citizenry around the dominant development strategy, urban elites confine the image of the city to monistic representations: the post-Fordist city, the postmodern city, the global and entrepreneurial city and, in more recent times, the sustainable and resilient city" (Rossi and Vanolo 2012, p. 26). One of the main points discussed throughout this chapter is the ongoing process which is slowly changing the representation of Palermo, or at least its historic city centre; this process is commonly considered a by-product of the neoliberal economic trends (Peck and Tickell 2002).

In many European cities, the changing representations of the city are mostly affected by a peculiar form of culture-led regeneration (Paddison and Miles 2006). Palermo is taking advantage of its cultural heritage to promote its role in a globalised and competitive society, trying to attract an ever-increasing flow of tourists. According to David Harvey's (1989b) ideas on entrepreneurialism, what 
has happened in many European cities (including Palermo) over the last 25 years can be interpreted as a late reproduction of the 'economic growth through culture' model. The ever-increasing rhetoric on the attractiveness of these cities as tourist destinations is clearly shown in several discourses that will be discussed later in this chapter. For now, suffice it to say that Palermo is not an extraordinary case at all; on the contrary, we are experiencing the (obvious) results of a late neoliberal attempt to include the city in the global economy of tourist attraction, not just as a hit-and-run destination.

Several small- and medium-sized European cities have experienced the same trends and changes over the last twenty years, as is the case for Bilbao (Keating and De Frantz 2004; Gonzalez 2006), Glasgow (Tratter 2009), Liverpool (Liu 2016) and, more recently, Matera (Bianchiand Fogheri 2016). Culture-led regeneration could not exist or exert its influence, if it were not supported by the 'politics of spectacle' (Harvey 1989a; Minca 2005): cities organise cultural exhibitions, festivals, concerts, etc. to prove their leading cultural role in the global world (as well as to become catalysts for visiting tourists, of course). The increasing importance of the role of culture for cities is unquestionably manifest if one looks at the list of European Capitals of Culture (Sykes 2011) and reflects on the way most of these cities have shaped their urban imagery in order to achieve a better, more broadly acknowledged status as a cultural tourism destination. Several projects and initiatives around Europe prove this trend, as in the case of the Rock project, whose motto is 'From Historic City Centre to Creative and Sustainable District' (https://rockproject.eu). It is no coincidence, of course, that most cities that have radically improved their tourist attractiveness have also been selected as 'capitals of culture', but for a few significant exceptions like Bilbao.

\subsubsection{Gentrification and Touristification}

"Since Glass coined the term 'gentrification' half a century ago in London, academic writing on gentrification has exploded and gentrification studies has become a field in its own right. [...] academic writing on gentrification has more than trebled between 1979 and 2016" (Lees 2018, p. 2). It would be impossible to summarise a long literature review on gentrification in a few lines (for a general review on gentrification, see Lees et al. 2008; Semi 2015). There are, however, a couple of points worth addressing, in order to strengthen the theoretical foundations of this chapter.

First, scholars are recently questioning the growing economic inequalities that gentrification and urban regeneration processes can produce (Smith 1996; Slater 2015): in the case of Palermo, we will analyse the social changes that gentrification is causing in the inner city and their aftermaths on the socio-economic status of the population. 'Regeneration' is the term that policymakers often employ instead of gentrification, as the latter seems to have a negative connotation that implies the progressive enrichment of the rich and the impoverishment of the poor, but "not only does 'urban regeneration' represent the next wave of gentrification, [...] but the 
victory of this language in anesthetizing our critical understanding of gentrification in Europe represents a considerable ideological victory for neoliberal visions of the city" (Smith 2002, p. 446).

Second, the role of art and culture in gentrification processes has been explored for several years now. Artists were considered the 'pioneers' of early gentrification, but more recently "the emphasis [...] is on the public consumption of art, through public art and artistic events, and particularly through the creation of landmark physical infrastructure for the arts, such as galleries, museums and concert halls" (Cameron and Coaffee 2005, p. 46). Public urban policies are spurring the increase in art events, festivals and exhibitions, as noted above, and urban regeneration (i.e. gentrification) is strictly related to this increase. In fact, "over the past couple of decades, the arts have been placed in a position of privilege by city officials, development agencies, and private investors for their ability to catalyze and naturalize reinvestment in declining or underdeveloped areas of the inner city. This has resulted in the stimulation of gentrification to accelerate growth and development" (Mathews 2010, p. 672).

Third, gentrification caused by - or connected to-tourism is producing several changes in our cities, especially in Europe. This phenomenon, often referred to as touristification (Ashworth and Page 2011; del Romero Renau 2018), "is particularly important in peripheral economies that rely on tourism as a factor for development and growth. In other words, in places where the lack of highly paid professional jobs offers less possibilities for the occurrence of classical gentrification but, instead, where spaces are dominated by the purchasing power of visitors. In the Mediterranean, Caribbean or the Asia-Pacific region the arrival of visitors opens up new investment opportunities in the built environment and leads to a process of tourism urbanisation that includes not only large-scale resorts and second homes but also housing rehabilitation in historic areas. From a postcolonial perspective, this geography explains why tourism has been neglected in a gentrification literature that has traditionally focused on cities from advanced capitalist economies in the North" (Cocola-Gant 2018, pp. 281-282).

Fourth, touristification provokes the growth of short-term rentals and holiday rentals (Cocola-Gant 2016): a phenomenon that is now called airbnbfication due to the importance of AirBnB (Wachsmuth and Weisler 2018). Although this is happening all over the world, the increase in short-term rentals is very impressive in Europe, and particularly in Italy (Semi and Tonetta 2020). Needless to say, in the case of Palermo, holiday rentals have grown in numbers and importance since the 'Palermo renaissance', and though this point would require an in-depth analysis that cannot be provided in this chapter, the topic is of utmost importance and deserves further investigation. 


\subsubsection{Connections}

The four abovementioned points prove how strong the relationships between such notions as place identity, urban representations, art and culture, tourism and gentrification are. Some of these relationships (e.g. the link between gentrification and culture) have been thoroughly investigated since the appearance of the so-called 'third wave of gentrification' (Mathews 2010), while others, most notably the one between place identity and gentrification, still require additional scholarly reflections. The goal of this chapter is therefore to lay down the bases for a theoretical framework that can link these notions through the empirical analysis of what is happening in Palermo today.

One last word of caution needs to be mentioned, though. It would be a mistake to apply the Anglo-American models of gentrification, urban imagery and place identity to a Southern Mediterranean case like Palermo, without any adaptation. This chapter will, instead, use a postcolonial, comparative approach (Robinson 2011) and consider Southern Europe, and Palermo in particular, as a unique and diverse case (Seixas and Albet 2012; for additional details on this post-colonial, comparative, Southern European approach to the case of Palermo see Bonafede and Lo Piccolo 2010; Picone 2016; Tulumello and Picone 2016).

\subsection{A Qualitative Methodology for Gentrification Studies in Palermo}

Choosing a specific methodology over another has a direct impact on the results of any research. Although this is true for every research in social sciences, in the case of gentrification this issue has been well addressed by sociologist Japonica Brown-Saracino: "qualitative scholars, typically relying on micro-level analyses of individual neighborhoods, tend to present gentrification as increasingly endemic, advanced, and highly consequential, whereas quantitative scholars, typically relying on macro-level analyses across neighborhoods or cities, tend to present gentrification in less dire terms" (Brown-Saracino 2017, p. 516). Since this chapter is trying to connect the topic of gentrification with urban representations and place identity, the choice of qualitative methodology is inevitable, as identity and representations belong to the qualitative domain of research in social sciences. Therefore, even acknowledging the significant information that quantitative techniques can provide, in the following pages I will present the results of qualitative analyses (DeLyser et al. 2010; Ilovan and Doroftei 2017), with very few references to the real estate market or tourist arrivals data. This may produce, at least in part, a distorted view of the gentrification trends in Palermo, but is arguably the most coherent choice that can be made. In the case of Palermo, there is still relatively little research on gentrification, as we will see later in this chapter; some studies apply quantitative 
techniques (Bonafede and Napoli 2015), while others seem much more qualitative in their nature (Jeanmougin and Bouillon 2016).

The following techniques have been used so far to collect qualitative data regarding the inner city of Palermo: interviews and focus groups, brainstorming and mental maps. A still ongoing action-research experience, based on a survey of the quality of life in the inner city of Palermo, has been promoted through the use of two participation techniques: Open Space Technology (Owen 2008) and World Cafés (Vogt et al. 2003). Additionally, this chapter will employ textual and discourse analysis (Dittmer 2010), along with visual methods (Crang 2010), to discuss a couple of newspaper or magazine articles on the 'resurrection' of Palermo.

\subsection{Portraits of Palermo: From Deprivation and Mafia to Culture and Tourism}

There follows a discussion of the changes that took place in the inner city of Palermo from World War II up to the present day. Considering the long time period and the complexity of the narration, we will split this story into three steps: from 1946 to 1991, from 1992 to 2017, and finally from 2018 onwards.

\subsubsection{Step 1: Cortile Cascino (1946-1991)}

At the end of World War II, Palermo suffered from several bombings by United States Army Air Forces (USAAF) and Royal Air Forces (RAF). In 1943, most parts of the inner city were severely damaged or totally destroyed. In the following decades, there were few effective attempts to restore the historic centre to its prior status; although regeneration plans were conceived from 1947, the effects of the war damage were still visible up to the last years of the 20th century. Living in the inner city was considered the only chance for the poorest of the population, with social and economic deprivation widely spread throughout the city centre.

Although the most well-known (at least to those who do not know the city firsthand) portraits of Palermo in these years is probably the Godfather movie trilogy, in this chapter I will leave popular culture behind, to stick to other, more truthful types of representation. One of the most famous portraits of the deprivation of the inner city is the documentary Cortile Cascino, released in 1962 in the United States and directed by Robert M. Young and Michael Roemer. It is interesting to point out that this documentary was actually never broadcast. NBC-TV, the distributor, deemed it too harsh for American viewers and decided to cancel it a few days before broadcasting (Fischer 2005). The documentary was inspired by field research that Danilo Dolci led in Palermo in the 1950s; see Pedone 2019 for an in-depth analysis 
of the situation in Palermo after WW2. A few scenes from Cortile Cascino can be seen on https://www.youtube.com/watch?v=IutIeAeSPFQ.

Cortile Cascino was one of the many courtyards in the inner city; after the extreme damage it received during the war, it was left in a very deprived state before being demolished in the late 1960s. Since we are focusing on the representations of the inner city, it is worth quoting a short description of this documentary: "The documentary begins with a train driving through the Palermo slum, and shots of children playing near the tracks. Mothers are shown supervising the kids, and doing chores like washing dishes; the men are a group apart, playing cards. Then we meet Adriana, the matriarch that anchors Cortile Cascino [...]. The narrator notes that the children of the neighborhood learn about life and death 'very early'; the images elaborate on this claim by showing boys butchering a hog, and scraping the pig's hair off its skin with a large knife" (Fischer 2005, pp. 48-49). Cortile Cascino also appears in several pictures from the 1950s and 1960s, showing the deprivation of the neighbourhood and its inhabitants. The choice of a 'vérité documentary', the description of the harshest scenes, the main subjects in the foreground of the pictures are all proof of this 'hellish' urban imagery of Palermo after WW2. The presence of criminal organisations (the mafia), poverty and ignorance are all part of it.

\subsubsection{Step 2: The 'Renaissance' of Palermo (1992-2017)}

In 1992, the death of two famous judges (Giovanni Falcone and Paolo Borsellino) killed by the mafia was the landmark of the period that later became known as the 'primavera di Palermo' (the spring of Palermo). During those years, left-wing mayor Leoluca Orlando, who today is once again the mayor of the city after several years of administration by right-wing parties, launched the guidelines for a 'renaissance' of the city, with the goal of turning Palermo from the capital of crime into a capital of culture. This approach is close to the ideas on urban entrepreneurialism described by David Harvey (1989b).

By exploiting the European Union's redistributive policies, particularly those on urban regeneration, Palermo grasped the opportunity provided by the URBAN I Community Initiative (1994-1999; see https://ec.europa.eu/regional_policy/sou rces/docgener/presenta/cities/cities_en.pdf). According to the Municipality, URBAN would 'allow the restoration of the historic centre, a fundamental step for the rebirth of the entire city'. What really matters here is the result of URBAN I: in October 2000, the rating agency Moody's assigned an Aa3 issuer rating to the city of Palermo. Moody's stated that “the rating is based on Palermo's improved city administration, its growing revenue base and moderate fiscal flexibility. [...] Palermo has undergone major political, cultural and economic changes during the second half of the 1990s, driven by the administration led by mayor Leoluca Orlando. [...] The municipal government's priorities have been to make the city more competitive and attractive to investors and to improve administrative efficiency. [...] At the same time, the administration has focused on transforming Palermo into an attractive historic city for 
tourists and international investors alike" (https://www.moodys.com/research/MOO DYS-ASSIGNS-Aa3-RATING-TO-THE-CITY-OF-PALERMO-PR_404930). The Aa3 rating was later withdrawn in 2006, but it was a crucial step in the transformation of the urban imagery of Palermo. Several keywords in the text above (competitive, attractive, efficiency, tourists) belong to the domains of entrepreneurialism, neoliberal politics and urban creativity (Florida 2002), and paved the way for the beginning of gentrification processes in the inner city.

The vast majority of urban renewal in the 1990s revolved around the Kalsa neighbourhood (Fig. 3.1). Most URBAN initiatives took place in the areas closer to the waterfront, and Kalsa was probably the best suited. The renewal of Piazza Magione, albeit slow, started to turn this deprived area-home to the poorest classes after the bombings - into a gentrified and attractive resource for the local economy. It took more than twenty years for the transformation to be completed, but its outcomes provided Palermo with a renewed and attractive representation that, for instance, increased the number of foreign tourist arrivals from 2017 to 2018 by $15.1 \%$ (https://www.comune.palermo.it/js/server/uploads/statistica/_260820190 82734.pdf). According to data collected for the Manifesta 12 event in Palermo, tourism attendance in the city went from 507,000 in 2011 to around 1,000,000 tourists in 2016 (Pestellini Laparelli 2018, p. 48).

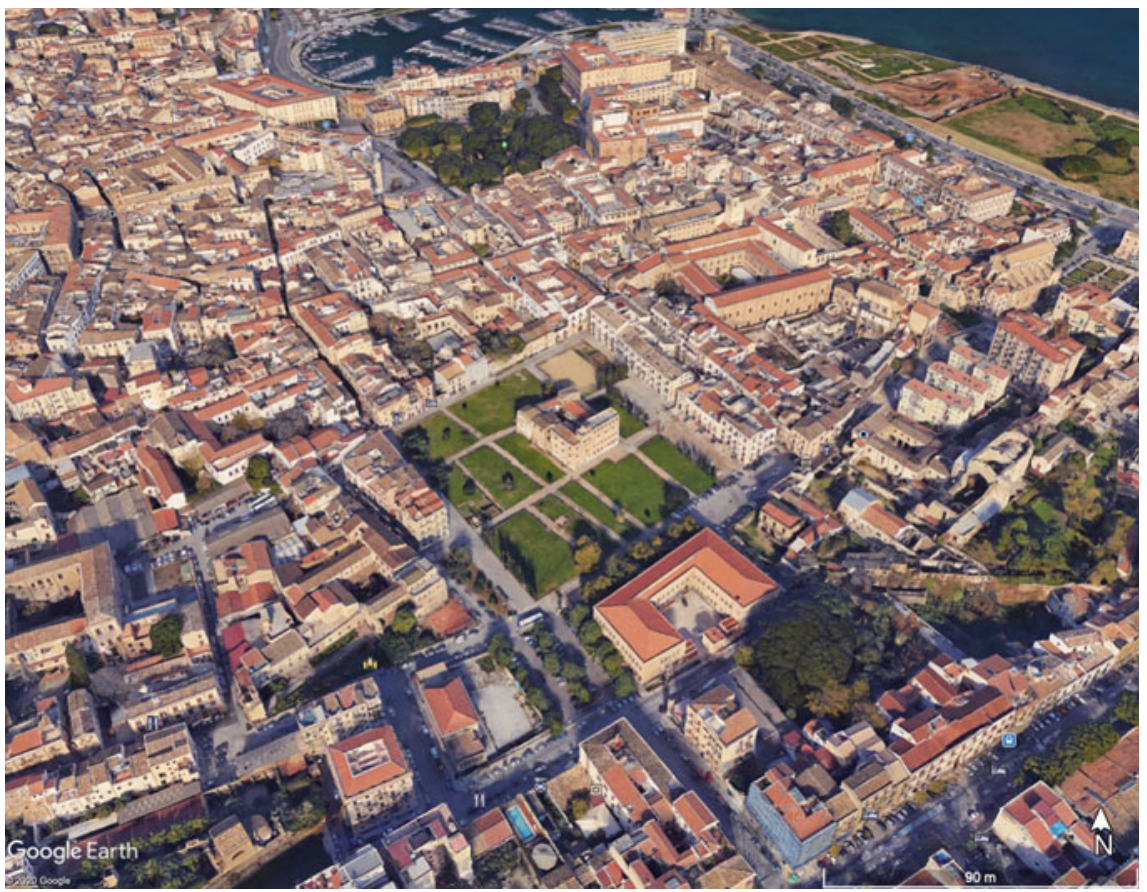

Fig. 3.1 The Kalsa neighbourhood. Aerial picture of Piazza Magione and its surroundings (Source Google Earth) 


\subsubsection{Step 3: Culture as an Urban Growth Machine (2018-)}

One of the key factors that explain this increase is the inscription of 'Arab-Norman Palermo' in the UNESCO World Heritage List (2014; see https:// whc.unesco.org/en/list/1487/), but two events in particular shaped the representation of Palermo and its historic centre: the nomination as Italian Capital of Culture (2018; see https://www.palermocapitalecultura.it/cultura-capitale/?lang = en) and the Manifesta 12 event (2018; see http://m12.manifesta.org). Manifesta is the 'European Nomadic Biennal' of arts and architecture and the following edition (Manifesta 13) was scheduled for September 2020, in Marseille, but the recent events tied to the pandemic spread of COVID-19 affected Manifesta, along with most festivals and exhibitions. The web site of the former provides this description: "Palermo, Italian Capital of Culture [ICoC], is a capital of Cultures, artistic culture and others, not only a full calendar of events but a vision that sees culture as a 'capital' around which the entire community will grow" (https://www.palermocapitalecultura.it/cultura-capitale/?lang = en); the latter, instead, shows a more bottom-up, progressive approach by stating that "Manifesta 12 in Palermo can act as a grass-root incubator supporting the local communities with cultural interventions: this will help to rethink the city in their socioeconomic and cultural structures and will use the existing informal profile of the city to act as a platform for social change" (http://m12.manifesta.org/why-palermo/). Both messages, however, stress the importance of culture for economic growth, which is the foundation of the neoliberal approach to the city (Peck 2005). The title of this section is an adaptation of the famous 'city as a growth machine' definition by Harvey Molotch (Jonas and Wilson 1999), but it stresses the role of culture as the main driver of urban growth. In this sense, Palermo is an interesting Mediterranean case of how culture and touristification are used to change the representation of the city. The historic centre is portrayed as a living and creative urban lab for culture and social inclusion: Fig. 3.2 is one of the many examples of how Manifesta 12 presented previously deprived parts of the inner city, now home to artists and art projects. The traditional characteristics of Palermo provide inspiration for artists and creative people and (supposedly) consecrate the 'renaissance' of the city.

\subsubsection{Afterword: Did the Quality of Life Improve in Palermo?}

Palermo's late attempt to exploit its cultural heritage for economic growth caused several consequences in the city, gentrification and touristification arguably being among the most manifest ones. There are, however, other changes also affecting the city. I have recently taken part in an ongoing action-research experience on the Quality of Life (QoL) in the inner city of Palermo. Its goal of was to question the most well-known QoL classification in Italy: the annual report on QoL in Italian cities published yearly by Il Sole 24 ore (https://lab24.ilsole24ore.com/qualita-della-vita/). 


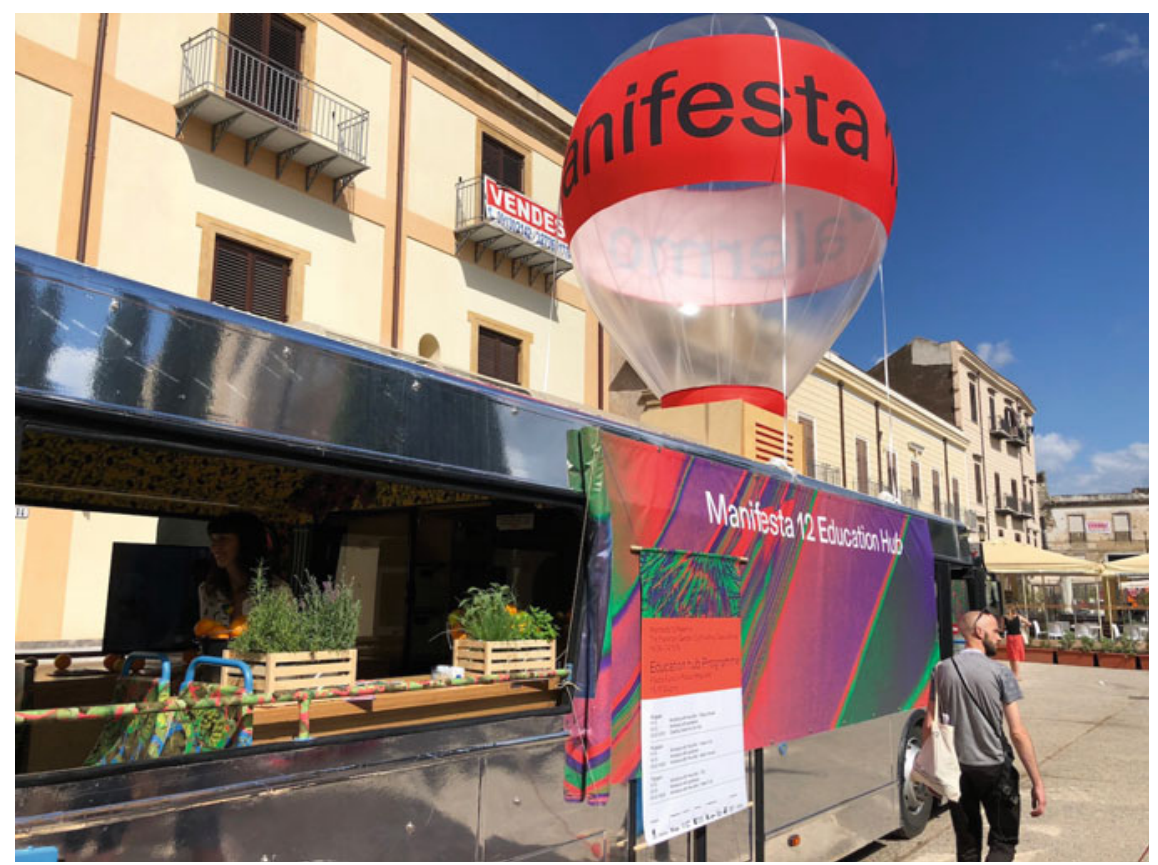

Fig. 3.2 Manifesta12 education hub in Piazza Magione, the heart of the Kalsa neighbourhood (Photo by Marco Picone)

According to this report, Palermo has always performed badly and attained the lower rankings; in 2018, the year of Manifesta 12 and ICoC, the city reached its highest peak, but still ranked 87th over 107 cities in Italy. The research on QoL in Palermo starts with the idea that QoL cannot only be ascertained through quantitative analyses, but requires qualitative, in-depth investigations as well. To this end, the research group of 'qualiPA' (https://www.facebook.com/qualipa/) has organised several interviews and focus groups, and used participation techniques as an Open Space Technology meeting (Owen 2008) and a World Café event (Vogt et al. 2003) to collect data on the perceptions of the latest changes in QoL in Palermo.

The results of these investigations are still unpublished but prove significant to understanding how the urban imagery of the inner city has changed so far. One of the topics discussed during the World Café meeting held on October 28, 2019 is how the neighbourhood around Piazza Magione (Kalsa) has changed over the last few years. Participants shared the idea that urban regeneration (i.e. gentrification, although they never used this term) has improved the overall quality of life in the inner city, also improving the perceived safety of the neighbourhood. Many of them stressed the importance of the 'sense of belonging' and community in the inner city and said that the new residents (i.e. the gentrifiers) are trying to strengthen their relations with the previous residents (i.e. the members of the poorer classes). Although these relationships are actually all but peaceful and are causing several conflicts over the use 
of spaces and resources, it is important to notice that both social groups agree upon the general perception of what has changed in the inner city, and how positive this change is. The perceived improvement of QoL is actually connected to the shifting imagery of the city, as this chapter has tried to point out.

\subsection{Conclusions}

Before concluding this analysis of the shifting imagery of Palermo, I will return to the three theoretical concepts described above to see how they relate to what has been going on in Palermo over the last few years.

I will start by discussing place identity and the territorial implications of the sense of belonging. As residents of the historic centre stated during the abovementioned World Café meeting, the inner city is experiencing an apparently peaceful but also growing conflict between gentrifiers and previous residents. Although this kind of conflict is quite common in all gentrification processes, the response to this is not the same as in US or Northern European cities. The arrival of the new residents has not (yet) driven the old residents out of the inner city, both for economic reasons and, arguably, because these processes follow different paths in Southern Europe. This involuntary coexistence is producing a new sense of identity that is still worth exploring through additional qualitative investigations.

As for urban imageries, what is happening in Palermo right now is the consequence of a complex global trend: "cities become central places in the production and regeneration of cultures, symbols, fashions and meanings transgressing the physical boundaries of the city itself and exerting an increasing influence on the broader cultural and economic practices in contemporary societies" (Rossi and Vanolo 2012, p. 34). Both textual analysis and visual methods show this shift from a negative past to a presumably positive present: whereas after WW2 and before 1992 the widely spread image of the city revolved around crime, the mafia and the urban deprivation of Cortile Cascino, urban renewal initiatives are forging a new image of the city which is strategically employed to attract tourists. Palermo possesses a cultural heritage which is certainly worth visiting, but the ICoC reference to "culture as a capital" plays upon the double meaning of 'capital' as a geographic and economic term, revealing the capitalist and neoliberal use of culture and laying the foundations of a new representation, in which culture and arts become key elements of urban marketing processes. What will happen to the poorest in a cultural, capitalist, neoliberal and gentrified inner city still remains an open question.

Considering the role of gentrification and touristification in Palermo implies evaluating the strengths and weaknesses of the unique Southern European approach to these topics. The postcolonial perspective that Cocola-Gant (2018) invokes suggests appraising the differences and similarities between advanced capitalist cities and the 'marginal' case of Palermo. The history of gentrification in Palermo fails to comply to the waves of gentrification described in Anglo-American literature and follows an eccentric trend. The explanation of what urban policies are trying to achieve 
in Palermo probably lies in touristification and culture-led urban renewal, but the precise characteristics of these trends should be evaluated with a mixed approach that includes both quantitative and qualitative methods.

Overall, the present years are altering and shaping the image of Palermo in ways that were hardly conceivable no more than 20 years ago. The possible success of these attempts will only be assessed in the future, but these changes raise several questions related to social justice and the role of participation in empowering citizens and granting them the opportunity to decide the future of their city.

\section{References}

Ashworth, G., \& Page, S. J. (2011). Urban tourism research: Recent progress and current paradoxes. Tourism Management, 32(1), 1-15.

Banini, T. (2017). Proposing a theoretical framework for local territorial identities: Concepts, questions and pitfalls. Territorial Identity and Development, 2(2), 16-23.

Bianchi, A., \& Fogheri, A. M. (2016). La rigenerazione urbana «culture-led» . Un percorso da intraprendere a Matera. Rivista economica del Mezzogiorno, 4, 989-996.

Bonafede, G., \& Lo, Piccolo F. (2010). Participative planning processes in the absence of the (public) space of democracy. Planning Practice and Research, 25(3), 353-375.

Bonafede, G., \& Napoli, G. (2015). Palermo multiculturale tra gentrification e crisi del mercato immobiliare nel centro storico. Archivio di Studi Urbani e Regionali, XLVI(113), 123-150.

Brown-Saracino, J. (2017). Explicating divided approaches to gentrification and growing income inequality. Annual Review of Sociology, 43, 515-539.

Cameron, S., \& Coaffee, J. (2005). Art, gentrification and regeneration-From artist as pioneer to public arts. European Journal of Housing Policy, 5(1), 39-58.

Cocola-Gant, A. (2016). Holiday rentals: The new gentrification battlefront. Sociological Research Online, 21(3), 112-120.

Cocola-Gant, A. (2018). Tourism gentrification. In L. Lees \& M. Phillips (Eds.), Handbook of gentrification studies (pp. 281-293). Cheltenham: Edward Elgar Publishing.

Crang, M. (2010). Visual methods and methodologies. In D. DeLyser, S. Herbert, S. Aitken, M. Crang, \& L. McDowell (Eds.), The SAGE Handbook of Qualitative Geography (pp. 208-224). London: Sage.

Cresswell, T. (2004). Place: A short introduction. Malden, MA: Blackwell.

del Romero, Renau L. (2018). Touristification, sharing economies and the new geography of urban conflicts. Urban Science, 2(4), 104.

DeLyser, D., Herbert, S., Aitken, S., Crang, M., \& McDowell, L. (Eds.). (2010). The SAGE Handbook of Qualitative Geography. London: Sage.

Dittmer, J. (2010). Textual and discourse analysis. In D. DeLyser, S. Herbert, S. Aitken, M. Crang, \& L. McDowell (Eds.), The SAGE handbook of qualitative geography (pp. 274-286). London: Sage.

Elden, S. (2010). Land, terrain, territory. Progress in Human Geography, 34(6), 799-817.

Fischer, C. (2005). NBC white paper, Cortile Cascino, and the assault on the familiar. In L. Lewis (Ed.), Robert M. Young: Essays on the films (pp. 43-55). Jefferson: McFarland \& Company.

Florida, R. (2002). The rise of the creative class: And how it's transforming work, leisure, community and everyday life. New York: Basic Books.

Friedmann, G. (2010). Place and place-making in cities: A global perspective. Planning Theory and Practice, 11(2), 149-165.

Gonzalez, S. (2006). Scalar narratives in Bilbao: A cultural politics of scales approach to the study of urban policy. International Journal of Urban and Regional Research, 30(4), 836-857. 
Harvey, D. (1989a). The condition of postmodernity. Oxford: Blackwell.

Harvey, D. (1989b). The urban experience. Baltimore: Johns Hopkins University Press.

Ilovan, O.-R., \& Doroftei, I. (Eds.). (2017). Qualitative research in regional geography: A methodological approach. Cluj-Napoca: Presa Universitară Clujeană.

Jeanmougin, H., \& Bouillon, F. (2016). D'une gentrification inaboutie à une «nouvelle précarisation» ? Continuités populaires et conflits de coprésence dans le centre historique de Palerme. Lien social et Politiques, 77, 103-125.

Jonas, A., \& Wilson, D. (1999). The urban growth machine: Critical perspectives two decades later. New York: SUNY Press.

Keating, M., \& De Frantz, M. (2004). Culture-led Strategies for urban regeneration: A comparative perspective on Bilbao. International Journal of Iberian Studies, 16(3), 187-194.

Lees, L. (2018). Introduction: Towards a C21st global gentrification studies. In L. Lees \& M. Phillips (Eds.), Handbook of gentrification studies (pp. 1-12). Cheltenham: Edward Elgar Publishing.

Lees, L., Slater, T., \& Wyly, E. (2008). Gentrification. London and New York: Routledge.

Liu, Y. (2016). Cultural event and urban regeneration: Lessons from liverpool as the 2008 European capital of culture. European Review, 24(1), 159-176.

Massey, D. (2005). For space. London: Sage.

Mathews, V. (2010). Aestheticizing space: Art, gentrification and the city. Geography Compass, 4(6), 660-675.

Minca, C. (Ed.). (2005). Lo spettacolo della città. Padua: CEDAM.

Owen, H. (2008). Open space technology: A user's guide. San Francisco: Berrett-Koehler.

Paasi, A. (2003). Region and place: Regional identity in question. Progress in Human Geography, 27(4), 475-485.

Paasi, A. (2010). Regions are social constructs, but who or what 'constructs' them? Agency in question. Environment and Planning A, 42(10), 2296-2301.

Paddison, R., \& Miles, S. (Eds.). (2006). Culture-led urban regeneration. London and New York: Routledge.

Peck, J. (2005). Struggling with the creative class. International Journal of Urban and Regional Research, 29(4), 740-770.

Peck, J., \& Tickell, A. (2002). Neoliberalizing space. Antipode, 34(3), 380-404.

Pedone, F. (2019). La città che non c'era. Lo sviluppo urbano di Palermo nel secondo dopoguerra. Palermo: Istituto Poligrafico Europeo.

Pestellini Laparelli, I. (Ed.). (2018). Palermo Atlas. Milano: Humboldt.

Picone, M. (2016). "Una segregazione paradossale e multi-scalare: il caso del quartiere ZEN di Palermo", Méditerranée. Revue géographique des pays méditerranéens, 127, 37-46.

Raffestin, C. (1980). Pour une géographie du pouvoir. Paris: Librairies Techniques.

Robinson, J. (2011). Cities in a world of cities: The comparative gesture. International Journal of Urban and Regional Research, 35(1), 1-23.

Rossi, U., \& Vanolo, A. (2012). Urban political geographies: A global perspective. London: Sage. Seixas, J., \& Albet, A. (Eds.). (2012). Urban governance in Southern Europe. Farnham: Ashgate.

Semi, G. (2015). Gentrification. Tutte le città come Disneyland? Bologna: il Mulino.

Semi G., \& Tonetta, M. (2020). Marginal hosts: Short-term rental suppliers in Turin, Italy. Environment and Planning A, online first, pp. 1-22. https://doi.org/10.1177/0308518X20912435.

Slater, T. (2015). Planetary rent gaps. Antipode, 49(1), 114-137.

Smith, N. (1996). The new urban frontier: Gentrification and the revanchist city. London and New York: Routledge.

Smith, N. (2002). New globalism, new urbanism: Gentrification as global urban strategy. Antipode, 34(3), 427-450.

Sykes, O. (2011). European cities and capitals of culture-A comparative approach. Town Planning Review, 82(1), 1-12.

Tratter, E. (2009). The cultures of capitalism: Glasgow and the monopoly of culture. Antipode, $41(1), 111-132$. 
Tuan, Y. (1977). Space and place: The perspective of experience. Minneapolis: University of Minnesota.

Tulumello, S., \& Picone, M. (2016). Shopping malls and neoliberal trends in Southern European cities: Post-metropolitan challenges for urban planning policy. Finisterra, 51(101), 111-132.

Vogt, E. E., Brown, J., \& Isaacs, D. (2003). The art of powerful questions: Catalyzing insight, innovation, and action. Mill Valley: Whole System Associates.

Wachsmuth, D., \& Weisler, A. (2018). Airbnb and the rent gap: Gentrification through the sharing economy. Environment and Planning A: Economy and Space, 50(6), 1147-1170. 